\title{
Translation Strategies Used in Behaviourist, Cognitive, and Constructivist Approaches to Translation Instruction
}

\author{
Minoo Pourfarhad \\ Ph.D. Candidate of TEFL, Hakim Sabzevari University, Iran, mnprfrhd@yahoo.com
}

\begin{abstract}
Mohammad Davoudi
Asst. Prof., corresponding author, Hakim Sabzevari University, Iran, davoudi2100@gmail.com
\end{abstract}

\section{Gholamreza Zareian}

Asst. Prof., Hakim Sabzevari University, Iran, zareian22@gmail.com

\section{Seyyed Mohammad Reza Amirian}

Asst. Prof., Hakim Sabzevari University, Iran, smr.amirian@gmail.com

The present study was an attempt to investigate the strategies emerging in the translation classes instructed through different approaches, namely behaviourist, cognitive and constructivist. One hundred twenty homogeneous senior students at upper-intermediate level of proficiency studying English Translation in the Iranian context took part in the study. The selected participants were randomly divided into four groups. Oxford Placement Test, pre- and post-tests of translation performance, and portfolios were used as instruments for collecting the data. The participants went through the processes of pretesting, intervention, and post testing. Analysis and categorization of the strategies learners employed to translate more creatively and appropriately revealed that a) focusing on the diction of the words, b) concentrating on the complex structures used by different writers, and c) making use of the equivalents they became interested in or found suitable, were the most frequently referred to strategies used by the learners. The findings of the descriptive analysis revealed that Iranian EFL students majoring in English translation enjoy high potential to initiate specific strategies to solve their problems in developing their translation ability. The findings of the study could be employed by translation community members and EFL instructors in Iranian schools, universities, and language institutes.

Keywords: translation strategies, behaviourism, cognitivism, constructionism, translation instruction, interpretation

Citation: Pourfarhad, M., Davoudi, M., Zareian, G., \& Amirian, S. M. R. (2018). Translation Strategies Used in Behaviourist, Cognitive, and Constructivist Approaches to Translation Instruction. International Journal of Instruction, 11(4), 139-158. https://doi.org/10.12973/iji.2018.11410a 


\section{INTRODUCTION}

Teaching and learning translation, as well as the strategies translators and translation students employ in the process of translation, have advanced to a level to form a specific discipline entitled as "Translation Studies". Meanwhile, most of the studies conducted in the area of translation training have focused on the models of translation (Kiraly, 2014). As Zhao, Hassan, \& Auli (2015, p. 1527) assert, "Translation models often fail to generate good translations for infrequent words or phrases". On the other hand, the teaching/learning process in the domain of teaching English as a foreign language (TEFL) has vastly focused on the implications of translation in the second language (L2) teaching (Cook, 2013). Howatt and Smith (2014) assert that rejection of translation in teaching foreign languages has been questioned by second language acquisition (SLA) research. Also, they discuss that neglecting translation as a teaching technique has sometimes led to undesirable consequences such as meaningless and inappropriate language use.

Munday (2016, p. 316) asserts that we can investigate new translation phenomena in the light of existing theoretical frameworks. There are two basic features of translation process: translation problems and translation strategies. The description of translation problems has always been assumed as one of the most favourite aspects of translation pedagogy. A variety of strategies have been proposed in the literature for solving these problems. If the concept of translation pedagogy is of any empirical value, it should somehow be lined to translation problems.

As translation and interpretation have nowadays gained enough power in the domain of translation studies, teaching translation strategies has absorbed the attention of scholars worldwide (Kiraly, 2015). In this regard, the present study is an attempt to compare the translation strategies employed by EFL translation learners instructed through Behaviouristic, Cognitive, and Constructivist perspectives.

\section{REVIEW OF THE RELATED LITERATURE}

Translating process is not only a hard task but also a very significant one. The importance of translation in today's world is crystal clear (Devy, 1999; Hanks \& Severi, 2014; Hutchings, 2001). However, wrong translations and interpretations have led to irreparable mistakes in knowledge areas such as science, medicine, legal matters, or technology. As Colina (2003) urges, scientific training of translators and interpreters is of prime significance. Professional translators should be equipped with enough scientific knowledge and information as well as bilingual verbal ability to come over the problems of translating and translation. Translation ability is nowadays accounted as one of the language skills and, as Hatim and Munday (2004) state, translation and interpretation studies have attracted a great deal of attention and this appears to be affected by the temporal and special needs and demands of academic and industrial circles. "The advances and developments in science and technology and the need to exchange the newly-developed information, knowledge and technology in native speakers' countries highlight a deep demand to train professional translators" (Alavi \& Ghaemi, 2013, p. 18). 


\section{Theories}

Behaviourism associates learning with changes in observable performance. When a suitable response happens in response to an environmental stimulus, learning takes place. In behaviourism, the important parts are the stimulus and the response. All behaviours are also learned through interaction with the environment (Fisher, 2011). Watson who is reputed to be the father of behaviourism (as cited in Brown, 2007), defined learning as sequence of stimulus and response actions in observable cause and effect association. The behaviourists' classical example shows that the process in which a human learns to respond to a neutral stimulus is usually related to an unconditional stimulus. B. F. Skinner (as cited in Burns, \& Richards, 2009) is one of the pioneer theorists who expanded the fundamentals of behaviourism which were started by Watson (ibid). Based on Skinner's views, automatic behaviour can be either weakened or strengthened by instant presence of punishment or reward (Driscoll, 2005).

Mitchell and Myles (1998) assert that behaviourism is the result of the broadly held conviction specifying that "careful discipline brings about promising results". Relying on this perspective, EFL students will have the capacity to improve their target language through supported impersonation and redundancy. In spite of significant feedback and experimental proof, behaviourism has impacted both foreign language teaching method and examination in second language learning (Howatt, 2000).

As Allwright (2005, p. 11) suggests, the label 'cognitive code' "captures both the nature of the mental operations involved and the focus on the language system". Byram (2004) also argues that cognitive theory is characterized by conscious acquisition of language as a meaningful system, cognitive psychology and transformational grammar. In other words, cognitive theory has been formed around the reframed notions of linguistics and psycholinguistics proposed by Chomsky (Celce-Murcia, 2015).

Both behavioural and cognitive theories are objectivistic; i.e., the world is real and external to the learner and that is why instructional approaches related to constructivism attempt to illustrate the structure of the world to the learner (McLeod, 2003). Man, as a social being, is in close contact with the world around him and that is why what he learns is affected by the environment in which he grows. Constructivists consider learning as a socially oriented process in which everybody constructs his legitimate version of reality. Meanwhile, different versions of a reality developed by various individuals should be combined together to initiate a valuable and useful social movement (Illeris, 2004).

Nevertheless, constructivism is assumed to be a branch of cognitivism because both of them consider learning as a mental activity but constructivism theory associates learning with producing meaning from experience. According to Wells (2007, p. 1), "Constructivism theory claims that knowledge is independent from the mind and can be "mapped" onto a learner". Classrooms, in view of constructivist intuition, vary from common teacher-focused or learner-focused classes in various ways. In constructivism, classrooms are considered learning situations where learners are permitted to take an interest in what they like. In fact, classrooms based on constructivist approach present a 
situation where doors are opened for learners and they are encouraged to develop interpersonal relations and build up their individual personalities, and where members progress toward getting to be deep-rooted learners (Kumaravadivelu, 2006). Greeno, et al. (1996) stress that the disciplinary practices and discourse practices of the class ought to be designed for the necessities of the students.

It is critical to mention, however, that constructivist instructional procedures are not instructive panacea and they are, by all account, not the only path for students to develop meaning (Burkett, 2014; Howard, Di Eugenio, Jordan, \& Katz, 2017; Mukhari, 2016). Students construct their own knowledge and interpretations no matter what instructional approach is implemented and no matter what name is given to it (Hackbarth, 1996; Struyven, Blieck, \& De Roeck, 2014). Thus, no single teaching method ought to be used exclusively. Indeed "conventional" transmission techniques, for example, retention and repetition learning can prompt helpful development of information (Janicki, Schell, G., \& Weinroth, 2000). As Glasersfeld (1995) asserts, "there are, indeed, matters that can and perhaps must be learned in a purely mechanical way" (p. 5). The task of the teacher, then, is to find a harmony between exercises that empower students to build information and those that transmit information to learners.

The hypotheses and constructs connected with constructivism and social constructivism are starting to have a greater impact on instructive thought, practice, and educational planning. Specialists and professionals in various disciplines have tried to enhance their understanding about constructivism and apply the hypothetical principles of constructivism in the form of a well-thought-out and manageable instructional approach. (Kiraly, 2015).

In a project-based classroom, students look for answers to problems by discussing various aspects of a problem, talking about, foreseeing, and outlining plans and examinations, gathering and dissecting information, making conclusions, imparting their discoveries to others, thinking about their work, and making relics (Blumenfeld, Soloway, Marx, Krajcik, Guzdial, \& Palincsar, 1991). While there is no authoritative or extensive list for the constituent segments of task-based learning, Blumenfeld et al. (1991) propose two basic and characterizing segments: (a) projects must have an inquiry or issue that sorts out and coordinates the consequent exercises, and (b) the exercises result in products, or artefacts, that come full circle in a last product that addresses the starting inquiry or issue.

\section{Translation Instruction}

According to Kuscu and Unlu (2015), "the role of translation in our lives is of great importance as translation has always enriched human life as a tool for communication and sharing information across the world" ( $p$. 407). There is a widespread wrong conviction that everybody can do translation and interpretation even if they lack an academic training. Some others (Dijkstra, T., \& Rekké, 2010; Lesznyák, 2007; McQuillan \& Tse, 1995; Pavlenko, 2009) believe bilinguals or those who use bilingual dictionaries are able to translate and; therefore, courses in interpretation are not useful and could be considered exercises in futility. 
Nida (2004), notwithstanding, attests that regardless of such reactions to translation instruction, there has been a requirement for teaching and direction in figuring out how to interpret. In fact, the non-academic individuals who have become extraordinary interpreters by means of minor useful experiences are special cases in this respect. Also, the expressive and etymological contrasts in the two languages involved in the process of interpretation might exacerbate the problems existing in the multifaceted nature of exchanging the ideas for the interpreters. That is why, instructing interpretation is a need among the disciplines of language educating.

\section{Translating vs. Translation}

Translating refers to oral translation or interpretation while translation mainly refers to the rendering of written documents from one language to another (Nida, 1993; Nord, 2005; Munday, 2015). Also, translating is said to be a process-oriented activity whereas translation is considered product-oriented.

The requirement for the introduction of interpretation hypothesis/theories in translation training for numerous students and many instructors is not fully taken care of in the present state of the field. It is discussable that most skilled interpretation specialists in interpretation studies had never received any sort of formal or academic instruction (Nida, 1993; Nord, 2005, Munday, 2015). The capable specialist who is not equipped with any sort of formal preparation when translating logically adds to an arrangement of interpretation techniques that are subliminally actuated. For instance, while experiencing an informal or a famous expression, he or she first searches in the target language for a comparing expression. Above all, along these lines, we ought to make a sharp distinction between a hypothesis of interpretation and a hypothesis of interpreting.

First, a hypothesis of interpreting consists of an arrangement of reasonable standards and rules which are naturally actualized in interpretation practice and is subliminal. In contrast, a hypothesis of interpretation consists of an arrangement of hypothetical or theoretical standards and rules which are formally learned and deliberately connected by interpreters and it is conscious (Nord, 2005).

Second, through broad interpretation movement wherein the arrangement of standards and rules achieves a high level of automatization in experienced interpreters, a hypothesis of interpreting is actually procured through experiences and presentations, while a hypothesis of interpretation is formally learned as its hypothetical cases are tried against normally happening or created translational information.

Gradually, native speakers get familiar with the ups and downs of their languages which empower them enough to viably participate in any type of formal training to utilize their language more skilfully. So, interpretation specialists also, through broad interpretation movement, gradually create adequate translational fitness. In both cases, a hypothesis is produced intuitively which could be labelled as Hypothesis of Conveying and Interpreting (Amrani, et al., 2008).

\section{Studies Conducted on Strategies in Translation}

Interpretation procedure needs focus on concepts beyond discovering theories in the target language or passing on the general meaning of the source language. To have a 
rendering which is satisfactory and reasonable, as the premise of translating, a few methods and techniques ought to be chosen. The goals of the interpretation methods by Nida (1993) are as follows: 1) "Giving alteration of the form of the message to the necessities of the structure of the target language, 2) Delivering structures which are semantically equal, 3) Giving equivalent stylistic propriety, and 4) Conveying an equivalent communication load" (p. 226).

Numerous discoveries (Jääskeläinen \& Trikkonen-Condit, 1991; Lörscher, 2005) propose that the overwhelming strategy of people with little involvement in interpretation comprises in supplanting expressions of one language with those of the other without more intricate content analysis. As noted by Lörscher, "most of the foreign language students produce translations mainly by an exchange of language signs" (Lörscher, 2005, p. 605). Tirkkonen-Condit comments that "novices tend to approach a translation task as a series of lexical or phrasal problems that are to be solved in the order in which they appear in the text. In novices' performance, translation tends to proceed word by word, phrase by phrase, sentence by sentence" (Tirkkonen-Condit, 2005, p. 408).

Then again, research conducted by Tirkkonen-Condit (2002), cited in TirkkonenCondit, 2005) demonstrates that an inclination to interpret literally happens in both learners and experienced interpreters. This is obvious in the interpretation process as well as in the completed interpretations. Tirkkonen-Condit claims that literal interpretation is the default system utilized by a person interpreting the content until that individual recognizes an issue with the content of the interpretation.

The inclination to interpret literally as a default method was initially noted by Newmark (1988) and then it was emphasized by Mandelblit (as cited in Tirkkonen-Condit, 2005) who did a psycholinguistic investigation in which bilinguals were requested to make an interpretation of colloquialisms from French into English and vice-versa. The results showed that "when translating DMC (different mapping condition) sentences, subjects tended to first suggest a word-to-word (and 'same mapping') translation for the source sentence and only later propose the better translation" (Tirkkonen-Condit, 2005, p. 409). Based on Lörscher (1991), interpretation forms observed in non-expert and expert interpreters have a considerable measure in common. He researched interpretation strategies utilized by foreign language learners and contrasted them with those utilized by expert interpreters. The aftereffects of his studies recommend that interpretation procedures observed in the two sets do not include huge contrasts; however, the procedures do vary in the recurrence and conveyance of various strategies (Lörscher 2005).

Similarly, as the contrasts between the interpretation techniques utilized by experts and non-experts are concerned, Tirkkonen-Condit states that novice interpreters and beginners concentrate on lexical units and look for data in outer interpretation aids, while specialists focus on the content itself, its semantic, inter-textual and pragmatic perspectives, attempting to elicit the data required as could reasonably be expected. The perception strategies of beginners have a local introduction, while those of specialists are worldwide and in line with the creation of new translation and interpretation 
strategies. The specialists tend to settle on some worldwide choices about the rising content of the interpretation (e.g. about its general style) at a moderately early phase of the procedure (Tirkkonen-Condit, 2005). These discoveries are in consonance with those of Jääskeläinen (1996).

As the present study was an attempt to investigate the comparative effect of teaching translation through behaviourist, cognitive, and constructivist approaches among Iranian students majoring in English translation and the strategies employed by the learners in each of these three strands, the following research question was proposed:

Which translation strategies emerge in behaviourist, cognitive, and constructivist approaches towards teaching translation to Iranian EFL learners?

\section{METHOD}

\section{Participants}

The participants of this study comprised 120 bilingual EFL learners studying English Translation in Islamic Azad University of Tabriz who were selected based on their performance on a standardized language proficiency test (Oxford Placement Test, Quick Test). To conduct the study, 120 students (samples) were selected out of the total 150 participants who were senior students majoring in English translation. The participants received a copy of the Quick Oxford Placement Test, which is a standard measurement device developed and verified by Oxford University. Considering the participants scores, the researchers selected 120 learners whose scores were between 31 and 47 as the upper-intermediate learners to take part in the study. The participants were both males and females with the age range of 18 to 25 . The participants were senior students studying English translation and were therefore familiar with translation activities. The selected participants were randomly divided into four groups (three experimental groups and one control group with 30 students in each). The instructor was one of the researchers with 16 years of experience in teaching translation to the Iranian EFL learners. She has been actively involved in training translators in the Islamic Azad University of Tabriz in the past sixteen years.

\section{Instrumentation}

To collect the required data, the researcher used Quick Oxford Placement Test (QPT), pre- and post-tests of translation performance, and portfolios. The following section describes the research instruments that were used in this study.

\section{Oxford Placement Test}

To assess the English language proficiency level of the participants, a standardized version of Oxford Placement Test was used. Oxford Placement Test (quick test, version 2 ) is in concordance with the European framework and is used to specify the proficiency level of students prior to the treatment and for placement purposes in the language institutes. The test has been frequently used in different studies and according to the Oxford University Exam Centre website (www.oxfordenglishtesting.com), the test enjoys a high reliability $(\mathrm{KR}-21=0.91)$. 


\section{Translation Performance Tests (pre-and post-tests)}

A translation activity task was performed by the participants. The texts used for this task were selected based on the proficiency level of the learners (upper-intermediate) and were put to the scrutiny of two experts in translation and TEFL. Hence, the overall validity of the translation tasks was reinforced. The texts were then put to the scrutiny of two experts in translation and TEFL. This was done to ensure the content validity of the texts which were used as the translation task. The texts were mainly covering the social, political, and educational themes. Each task included three to four passages and two parallel tasks were developed this way. The translation texts embedded in the tasks were both form Persian to English and vice-versa

\section{Learners' Records and Diaries}

To ensure if the participants had gone through schedules appropriately, and to see if they could get familiar with the strategies they had received to improve their abilities in translation, all the learners in different groups were trained to present diaries. The teacher, who enjoyed 20 years of experience in training translators at the academic level, was familiar with portfolios and their learning mechanism. Hence, she provided the learners with enough information concerning the diaries they were to develop. These diaries were presented in portfolios by the learners and also included the teachers' comments and feedbacks as well as the learners' reports on their own learning. As an example, one of the students had a note, "I thought using a bilingual dictionary was enough to do translation. Now I know not only it does not help me but impedes my understanding of the text."

Teacher's notes and suggestions for each session and for each learner were accommodated continuously and as the number of learners in each class was limited, it was possible for the teacher to check the students' problems in translation and to discuss the details of extra-curricular activities with them. For example, the teacher's notes on a student's translation foes as follows: "You had better read the text thoroughly and completely and then start translation." The teacher also developed an axial recording system of the data, based on each learner's diaries and evaluated the learner's progress based on a process-based, formative and qualitative mode. For example, for Saman, one of the learners, she had noted, "Saman is progressing well. In the beginning sessions, she did not pay attention to the purpose of the text, but now he considers this fact." This provided the researchers with the probable strategies the learners picked up, the extent to which they developed their translation and translating abilities, the frequency of the strategies employed, and the novelty of the strategies discovered by the learners.

\section{Procedure}

One hundred and fifty participants received a standardized proficiency test, namely Quick Oxford Placement Test (QPT), quick version and the ones whose scores fell at the upper-intermediate level (between 31 and 47) based on the standard scale, were labelled as the main participants of the study. The selected learners were randomly divided into four groups (three experimental groups and one control group with almost 30 students in each). Prior to the treatment, all the participants took a translation test as 
the pre-test in which they were asked to translate some passages from English to Persian and vice-versa to elicit the information and data needed for the purpose of the study. These texts were selected by the researchers based on their complexity level, content, and genre. To score the translation of students, the Translation Toolkit Evaluation of UTAH University (2013) was used.

\section{Intervention}

The treatment in all the four groups lasted 20 sessions. Each session was 90 minutes in which the participants of each group were exposed to both shared and differential, treatment- oriented activities. Half of the class time (45 minutes) was devoted to the shared activities for all the groups and the other half (45 minutes of the class time) was allotted to the specific treatment in each group. The learners attended the classes two times a week; therefore, they experienced the intervention for ten consecutive weeks. All the learners received shared and differential activities and instructions. The shared activities for all the four groups were as follows:

\section{Shared Classroom Activities}

All the learners in different groups received training in translation. They received the same texts, vocabularies, grammatical points, jargons, and idioms. The learners in all the groups were briefed about the portfolios as well and all of them were encouraged to keep portfolios of their developmental process in the translation classes. They were asked to report on the strategies they used in their translation activities (when translation was looked at as a product) and while translating (when translation was considered as a process). These measures helped the researcher categorize translation and translating strategies developed by students in each teaching method domain as well. The teacher (researcher) also kept diaries concerning what she did in each class and based on each method employed in the classroom. This helped her have a clear classroom program and lesson plan.

\section{Differential Instructions and Activities}

The experimental groups and the control group of the study received their specific trainings and instructions as follows:

Experimental group I: Experimental group I (Behaviouristic Group, BG hereafter) received its instructions based on the techniques rooted in the combination of behaviouristic learning and structuralism (Burns \& Richards, 2009). The techniques followed what is mainly found in the Audio-lingual Method and Situational Language Teaching (Larsen-Freeman, 2000). Though the idea of employing such a method in teaching translation was totally new, the techniques used in this teaching method were implemented in translation. Hence, the students were encouraged to practice text contraction, text expansion, transformation, Integration, repeating translations, target text restoration, source text modification and translation, translation completion, phrase replacement, restatement of translations done, and target text modification. 
Experimental group II: Experimental group II (Cognitivist Group, CG hereafter) followed the teaching techniques developed based on cognitive learning theory, or to put it more specifically, cognitive-code learning and teaching (Wilkins, 1990).

Kumaravadivelu (2006) categorizes all those methods that are principally concerned with cognitive process of language learning as learning-centred methods. He continues that "a preoccupation with meaning-making will ultimately lead to target language mastery...In this case, language development is more incidental than intentional"(p. 90). There are some points in his arguments that contrast with cognitive-code learning as a learning-centred method. He asserts that according to learning-centred pedagogists, even if there is no explicit grammar explanation, through focusing on meaning making, learners can internalize the grammar rules. Hence, the techniques used in teaching translation energized by cognitive code learning could be developed as follows:

Explicit teaching of texts, grammatical points and translation techniques were followed. Meaningful practice of translation from Persian to English and vice-versa were focused on and creativity in translation was encouraged. Analytical translation of texts based on Baker's (2010) criteria which considers semantics, syntax, textual issues, and pragmatics as well as critical thinking were focused on in this group. Any explanation given was followed by exercises in order to help the learners develop a translation competence cognitively (Alves, 2015). As cognitive learning could be defined as a process-based approach to learning, the process-oriented views in translation (Munday, 2015) was followed in developing exercises, tasks, and drills in translation; therefore, translating tasks, and not translation ones, seemed to be more in line with such a perspective. The learners in the CG were asked to provide the teacher (here the researcher) with their think-aloud protocols, strategy reports, and translating actions.

Experimental group III: Experimental group III (Constructivist Group, CNG hereafter) followed the main concepts of constructivism as well as the core concepts of cooperative learning and sociocultural theories of learning (Vygotsky, 1986).

Johnson (2004) argues that cooperative learning, scaffolding, and ZPD are the main concerns of any pedagogical program in the constructivist theory of learning. Accordingly, the students in the CNG group followed the techniques mostly followed in socio-culturally oriented programs (Eser, 2014; Lantolf, 2000). Working in cooperation, team work, peer correction, group translation, jigsaw techniques in translation, and scaffolding techniques, especially reciprocal scaffolding and peer/collective scaffolding (Babbitt, 2013) were put into practice in the translation activities of this group. This group received both peer-feedback and teacher feedback.

Control Group: The control group followed the conventional translation activities such as translating the texts and bringing them into classroom to be checked by the teacher. This type of exercise was translation-oriented and could be labelled as a productoriented activity (Munday, 2012). Therefore, this group mainly received teacher feedback (Ellis, 2008). However, because of the classroom atmosphere, a bit of selfcorrection and peer feedback was encouraged among the learners. 
Following the treatment, all the learners in the four groups received the post-test of translation performance to see if the treatment had significantly affected their translation performance.

\section{Qualitative Data Analysis}

The qualitative data were analysed through employing open coding and axial coding. The data were then analysed and the data derived was categorized, reported and scrutinized through covering the available literature. The learners' diaries, portfolios, and reports were analysed every day based on both descriptive and explanatory analyses as follows:

\section{Descriptive Analysis}

In the descriptive analysis, different views of translation observed by the teacher in the classroom(s) were distinctly recorded and described. The teacher's notes, suggestions, corrections and the like were categorized and mentioned. The learners' extent of development in each and every session was recorded and gradually a tentative, flexible and formative criterion was formed for the researchers, based on which they could analyse the learners' progress. This part included extracting the main points of diaries, categorizing the data and information gained through classroom observations, and the information represented in the learners' diaries.

\section{Explanatory Analysis}

The present study also employed explanatory analysis in which, based on the open/axial coding and structuring, explanations were presented. Hence, the results were classified and categorized in the frequency tables and explained. Therefore, the prominent and useful strategies employed by the learners while translating were also taken into consideration.

\section{FINDINGS}

The research question of the study, which was descriptive and qualitative in nature, aimed at investigating the translation strategies emerged in behaviourist, cognitive, and constructivist approaches towards teaching translation to Iranian EFL learners in the upper-intermediate level.

To answer this question which is qualitative in nature, all 120 participants of the study were trained to present diaries and portfolios. The prime assumption was to ensure if they went through programs, and could get familiar with the strategies they had received to improve their translation ability. These diaries shaped a portfolio for all learners and also included the teachers' comments and feedbacks as well as the learners' reports on their own learning. This also presented the researchers with the data required to find out the most prominent, successful translation strategies employed by the learners.

Both descriptive and explanatory analyses were employed to analyse the data collected. This provided the researchers with the types of translation strategies the learners picked up, the extent to which they developed translation ability, the frequency of the strategies 
employed, and the novelty of the strategies discovered by the learners. Table 1, represents the type, frequency, and percentage of the translation strategies the participants mostly employed in details.

Table 1

Type and frequency of the strategies the participants mostly employed

\begin{tabular}{|c|c|c|c|c|c|c|}
\hline \multirow{2}{*}{$\begin{array}{l}\text { Types of } \\
\text { Strategies }\end{array}$} & \multirow[t]{2}{*}{ Strategy Description } & \multicolumn{5}{|c|}{ Frequency Count } \\
\hline & & & Cog. & Const. & Control & total \\
\hline Cognitive & $\begin{array}{l}\text { Focusing on the written English structures (such as dangling } \\
\text { construction, subjunctive mood, inversion, and the like) and their } \\
\text { Persian equivalents as well as employing them in one's translations. }\end{array}$ & 22 & 18 & 14 & 11 & 65 \\
\hline $\begin{array}{l}\text { Socio- } \\
\text { affective }\end{array}$ & $\begin{array}{l}\text { Consulting with the teacher and using the translations and the } \\
\text { suggestions made. }\end{array}$ & 13 & 14 & 13 & 11 & 51 \\
\hline Cognitive & $\begin{array}{l}\text { Doing gist translation, summarizing texts, focusing on the content } \\
\text { maintenance, length, cohesion, cohesiveness, and other discourse } \\
\text { features. }\end{array}$ & 10 & 12 & 11 & 10 & 43 \\
\hline Cognitive & $\begin{array}{l}\text { Focusing on the text organization in translation and the placement of } \\
\text { various parts of a text based on the purpose and the genre type }\end{array}$ & 13 & 12 & 10 & 6 & 41 \\
\hline $\begin{array}{l}\text { Meta- } \\
\text { cognitive }\end{array}$ & $\begin{array}{l}\text { Planning and trying to translate into the target language (English) and } \\
\text { write the way target language writers (native speakers) write and } \\
\text { employing the same structures in new situations while translating } \\
\text { from Persian to English. }\end{array}$ & 10 & 9 & 9 & 8 & 36 \\
\hline $\begin{array}{l}\text { Meta- } \\
\text { cognitive }\end{array}$ & $\begin{array}{l}\text { Analysing source language texts and focusing on the methods of } \\
\text { writing, modes, moves, and the internal concepts presented in them, } \\
\text { then trying to keep the same in the target language reproductions. }\end{array}$ & 8 & 7 & 10 & 7 & 31 \\
\hline Cognitive & Keeping a portfolio of notes to be reviewed in case required. & 7 & 8 & 9 & 7 & 29 \\
\hline Cognitive & $\begin{array}{l}\text { Reading a lot of issues in English, specifically the main articles } \\
\text { covering the text under translation to get familiar with the concepts in } \\
\text { the text and copying the most interesting and most frequently used } \\
\text { structure and sentences to be used later, while translating. }\end{array}$ & 9 & 7 & 5 & 6 & 27 \\
\hline Cognitive & $\begin{array}{l}\text { Using bilingual dictionaries to find out the meaning of the words and } \\
\text { expressions and to follow the modelling presented in the examples in } \\
\text { case of translating from Persian to English, employing a diction- } \\
\text { oriented perspective. }\end{array}$ & 6 & 6 & 7 & 6 & 25 \\
\hline $\begin{array}{l}\text { Meta- } \\
\text { cognitive }\end{array}$ & $\begin{array}{l}\text { Focusing on the genre types and examining their differences in style, } \\
\text { diction, and form of presentation in both Persian and English. }\end{array}$ & 5 & 6 & 6 & 4 & 21 \\
\hline $\begin{array}{l}\text { Meta- } \\
\text { cognitive }\end{array}$ & $\begin{array}{l}\text { Following the creative modes found in the narratives and trying to } \\
\text { produce similar ones in the target language translations. }\end{array}$ & 6 & 4 & 4 & 4 & 18 \\
\hline $\begin{array}{l}\text { Socio- } \\
\text { affective }\end{array}$ & $\begin{array}{l}\text { Discussing, comparing, and contrasting the English and Persian } \\
\text { words, collocations, expressions, idioms, structures, and concepts } \\
\text { with friends and the teacher, connecting the notable structures, } \\
\text { collocations, etc... with the cultural concepts. }\end{array}$ & 5 & 4 & 4 & 3 & 16 \\
\hline $\begin{array}{l}\text { Meta- } \\
\text { cognitive }\end{array}$ & $\begin{array}{l}\text { Concentrating on the method of expansion and translating/ translation } \\
\text { development found in the course books of translation and using them. }\end{array}$ & 3 & 4 & 3 & 3 & 13 \\
\hline Cognitive & $\begin{array}{l}\text { Learning form authentic materials and following the way openings } \\
\text { and closings are developed in various situations and writing types } \\
\text { while translating from Persian to English }\end{array}$ & 4 & 3 & 3 & 2 & 12 \\
\hline $\begin{array}{l}\text { Socio- } \\
\text { affective }\end{array}$ & $\begin{array}{l}\text { Being open to criticisms to minimize the problems and also eradicate } \\
\text { them, whether presented through the teacher or peers. }\end{array}$ & 4 & 2 & 2 & 2 & 10 \\
\hline $\begin{array}{l}\text { Socio- } \\
\text { affective }\end{array}$ & $\begin{array}{l}\text { Seeking for the differences between English and Persian models of } \\
\text { writing to translate more accurately. }\end{array}$ & 2 & 2 & 2 & 2 & 8 \\
\hline $\begin{array}{l}\text { Socio- } \\
\text { affective }\end{array}$ & $\begin{array}{l}\text { Being very interested in consulting with working interpreters and } \\
\text { translators whenever possible (in the meetings, seminars, via the net, } \\
\text { and conferences). }\end{array}$ & 2 & 2 & 2 & 2 & 8 \\
\hline
\end{tabular}

A total of 454 common strategies were examined and categorized into 17 general learning strategy types. It is worth mentioning that the strategies reported enjoyed the classification presented by O'Malley, et, a1. (1985). According to the frequency of the 
strategies presented and based on the records of the learners' diaries, it could be concluded that cognitive strategies (items $1,3,4,7,8,9,14$ ), metacognitive strategies (items 5, 6, 10, 11, 13), and socio-affective strategies (items 2, 12, 15, 16, 17) were predominantly used by the learners to improve their translation development and learning to translate.

As it could be seen in the table, the most frequent strategies emerged among the learners of different groups fell in the domains of cognitive and metacognitive strategies. The constructivist group who received the highest score in their post-test of translation had reported they enjoyed cases $1,4,5,8,11,12,14,15,16$, and 17 while the cognitive group which was placed second in the ranking, had reported they enjoyed strategies 12 , $3,10,13,16$, and 17. For the behaviouristic group which came third in the ranking, cases $6,7,9,10,16$, and 17 had been absorbing. For the control group, cases 16 and 17 which fall in the area of socio-affective strategies had been interesting.

As Table 1 shows, the most frequent strategies for all groups are as follows:

a. Focusing on the English grammatical structures in translation and employing them in one's final work: structures such as dangling construction, subjunctive mood, inversion, and the like.

b. Consulting with the teacher and putting to application the suggestions made

c. Summarizing texts, focusing on the content maintenance, length, cohesion, cohesiveness, and other discourse features

d. Focusing on the text organization and the placement of various parts of the target language text based on the purpose and the genre type in the source language text

e. Planning and trying to write the way native speakers write in the target language and employing the same structures in new situations.

The less frequent strategies for all groups of learners dealing with translation development, as the Table1 shows, are as follows:

a. Being open to criticism to minimize the problems and also eradicated them, whether presented through the teacher or peers

b. Seeking for the difference between English and Persian models of writing, and

c. Being very interested in the writing/talking to/chatting with the translators and interpreters whenever possible (in the meetings, seminars, via the Internet, and conferences).

\section{DISCUSSION AND CONCLUSION}

It seems that both diction and structure have played effective factors in the betterment of learners' translations in all groups under experiments. It might be concluded that learners taking part in the study were absorbed by these two notions more than other points related to translating into their second language, English. The findings showed that focusing on characters of the translated stories and narrations, movies, creating 
imaginary readers, and practicing the use of cohesive devices have been among the less absorbing strategies for the learners of the study. The literature on translation development; however, presents these strategies among the most useful ones (Alves, 2015; Atherton, 2013; Eser, 2014; Montafej \& Nemati, 2014).

The reason might lie in the fact that experiencing translation development has been so novel an idea for the learners taking part in the study that they have not been able to delve into its various aspects. Also, they might have found getting familiar with the strategies successful translators employ difficult to master and time consuming. The other reason is that individual differences might have affected the learners' performance in developing translations in either of the two languages (Persian and English) and their strategy development.

The findings of the study, which relied on the learners' diaries and portfolio, also contributed to the idea that translation students can be better translators in case they employ different translation strategies. The findings of the descriptive analysis revealed that Iranian EFL learners enjoy high potential to initiate specific strategies to solve their problems while translating from Persian to English or vice-versa. As Oxford (1990) implies, the emergence of strategies and their frequency could be related to the immediate needs of the second language learners (and translators here and now) to solve their learning (or translating) problems. These strategies could be self-oriented, peersupported, or teacher-directed (Petersen, 2003).

This finding is in line with Liao's (2006) study on the EFL learners' beliefs and strategy use of translation in English learning, emphasizing that translation strategies such as focusing on the discourse features and focusing on grammatical structures help the development of translation among EFL learners. This finding can also take support from Alves's (2015) study on translation development among EFL learners in Spain, specifying that focusing on the text organization plays a significant role in correct translation. The studies conducted by SLA researchers (Cohen, 1998; Maftoon \& Amiri, 2012; McLeod, 2003; Phillips \& Soltis, 2009) and the ones in translation studies (Liao, 2006; Mogahed, 2011; Munday, 2015; Němec, 2011) also support the idea that "those who can employ more strategies effectively are better translator" (Kiraly, 2015, p.11).

While some personality characteristics such as being willing to take risks and being inquisitive seem to be useful in describing the successful translator, a number of other characteristics like motivation, attitude, aptitude, instruction, willingness to communicate, meta-cognition strategies, and autonomy seem to be very effective factors which could be further researched (Kiraly, 2015; Zhao, et al., 2015).

The findings reveal a pattern of strategy use emerging from the participants' portfolios which enables a strategy profile of the highly active students to be suggested. Based on the results of this study, the most proficient groups of students appear to use strategies which enable them to work consciously on their general reading comprehension ability and to interact frequently with the text in the target language. The findings of the study could be employed by EFL instructors and translation community members in Iranian schools, universities, and language institutes and elsewhere. Materials developers may 
use the findings of the present research to include more constructivist-oriented translation tasks in course book development. ESL and EFL teachers can make use of these findings in their classes to help the SL learners get more familiar with the creative translation strategies, critical thinking processes, self-esteem development, and the like in order to help them think and translate more creatively and appropriately.

Research indicates that translation drills and practices rooted in constructivist approach play an important role in students' achievements in developing translation ability into and from English as both a target and a source language (Atherton, 2013). The findings of the present study also stress that practicing translation, especially relying on constructivist and cognitive oriented types, could pave the way for the learners in an EFL situation to improve their performance in translating and translation.

Underlying assumption of constructivism is that all learners are capable of some degree of learning (change, modifiability) through cooperation (Kiraly, 2000). This contrasts with the underlying assumption of standardized psychometric behaviourist-oriented teaching, learning, and testing that the learning ability of most individuals is inherently stable (Waibel, 2015). Making a connection between the inside-class activities and outof-class tasks could expand the scope of learning and the time devoted to learning a second language or one of its skills or components. This is possible through employing constructivist approach as a specific view which encourages cooperation among the learners. Generally speaking, social constructivism encourages corporation, cooperation among the learners. It also helps the learner come up with a real understanding of his/her status of learning, his/her strengths and weaknesses, and through the feedbacks s/he receives, s/he will find the ways through which s/he can solve the ever-emerging problems of learning a second language and translation as a specific skill in this process.

\section{REFERENCES}

Alavi, S. M., \& Ghaemi, H. (2013). Reliability assessment and construct validation of translation competence questionnaire (TCQ) in Iran. Language Testing in Asia, 3(1), 18-33.

Alves, F. (2015). Translation process research at the interface. Psycholinguistic and Cognitive Inquiries into Translation and Interpreting, 115, 17-25.

Allwright, D. (2005). From teaching points to learning opportunities and beyond. TESOL Quarterly, 39(1), 9-31.

Amrani, N., Ghosh, S., Mangus, D. A., \& Jacobson, A. (2008). Translation factors promote the formation of two states of the closed-loop mRNP. Nature, 453(7199), 1276-1280.

Atherton, J. S. (2013). Learning and teaching; Constructivism in learning [On-line: UK] retrieved 17 May 2016 from http://www.learningandteaching.info/learning/constructivism.htm

Babbitt, P. (2013). Scaffolding: Strategies for improving reading comprehension skills. Pearson Prentice Hall: eTeach: Strategies for improving reading comprehension. Retrieved from http://www.phschool.com/eteach/language_arts/2002_12/essay.html 
Blumenfeld, P. C., Soloway, E., Marx, R. W., Krajcik, J. S., Guzdial, M., \&Palincsar, A. (1991). Motivating project-based learning: Sustaining the doing, supporting the learning. Educational Psychologist, 26(34), 369-398.

Brown, H. D. (2007). Principles of language teaching and learning ( $5^{\text {th }}$ Ed.). NY: Longman.

Burkett, L. B. (2014). Brain-based learning: A study on how teachers implement strategies in the traditional classroom (Doctoral dissertation, Capella University).

Burns, A., \& Richards, J. C. (2009). Second language teacher education. Cambridge University Press.

Byram, M. (Ed.). (2004). Routledge encyclopedia of language teaching and learning. New York: Routledge.

Celce-Murcia, M. (2015). An overview of teaching grammar in ELT. In M. Christison, D. Christian, P. A. Duff, \& N. Spada (Eds.), Teaching and learning English grammar: Research findings and future directions (pp.1-18). New York: Routledge.

Cohen, A. D. (1998). Strategies in learning and using a second language. New York: Addison Wesley Longman Limited.

Colina, S. (2003). Translation teaching: from Research to the classroom. New York: McGraw Hill.

Cook, V. (2013). Second language learning and language teaching. New York: Routledge.

Devy, G. (1999). Translation and literary history: Post-colonial Translation. London: Routledge.

Dijkstra, T., \& Rekké, S. (2010). Towards a localist-connectionist model of word translation. The Mental Lexicon, 5(3), 401-420.

Driscoll, M. P. (2005). Psychology of learning for instruction ( ${ }^{\text {rd }}$ Ed.).London: Pearson.

Ellis, R. (2008). The study of second language acquisition (2nd Ed.). Oxford: Oxford University Press.

Eser, O. (2014). Setting learning objectives in translation at the department of foreign language teaching through the concept of competence. Electronic Turkish Studies, 9(5), 21-30.

Fisher, T. (2011). Quine's behaviorism and linguistic meaning: Why Quine's behaviorism is not illicit. Philosophical Quarterly of Israel, 39(1), 51-59.

Glasersfeld, E. V. (1995). Radical constructivism: A way of knowing and learning. New York: Falmer Press. 
Greeno, J. G., Collins, A. M., \& Resnick, L. B. (1996). Cognition and learning. In D. C. Berliner \& R. C. Calfee (Eds.), Handbook of educational psychology (pp. 15-46). New York: Macmillan.

Hackbarth, S. (1996). The educational technology handbook: A comprehensive guide: process and products for learning. Educational Technology Publications, Englewood Cliffs, NJ.

Hanks, W. F., \& Severi, C. (2014). Translating worlds: The epistemological space of translation. HAU: Journal of Ethnographic Theory, 4(2), 1-16.

Hatim, B., \& Munday, J. (2004). Translation: An advanced course book. New York: Routledge.

Howard, C., Di Eugenio, B., Jordan, P., \& Katz, S. (2017). Exploring initiative as a signal of knowledge co-construction during collaborative problem solving. Cognitive Science, 41(6), 1422-1449.

Howatt, A. P. R. (2000). A history of English language teaching (2nd Rd.). Oxford: Oxford University Press.

Howatt, A. P. R., \& Smith, R. (2014). The history of teaching English as a foreign language, from a British and European perspective. Language \& History, 57(1), 75-95. DOI: $10.1179 / 1759753614 Z .00000000028$

Hutchins, J. (2001). Machine translation and human translation: In competition or in complementation. International Journal of Translation, 13(1-2), 5-20.

Illeris, K. (2004). The three dimensions of learning. Malabar, Fla: Krieger Pub. Co.

Jääskeläinen, R. (1996). Hard work will bear beautiful fruit: A comparison of two thinkaloud protocol studies. Meta, XLI/1, 60-74.

Jääskeläinen, R. \& S. Tirkkonen-Condit. (1991). Automatized processes in professional vs. non-professional translation: A think-aloud protocol study, In Tirkkonen-Condit, S. (ed.), Empirical research in translation and intercultural studies (pp.89-109). Tübingen: Narr.

Janicki, T. N., Schell, G. P., \& Weinroth, J. (2002). Development of a model for computer supported learning systems. International Journal of Educational Technology, 3(1), 1-16.

Johnson, M. (2004). A philosophy of second language acquisition. London: Yale University Press.

Kiraly, D. (2000). A social constructivist approach to translator education: Empowerment from theory to practice. Manchester: St. Jerome Publishing.

Kiraly, D. (2014). A social constructivist approach to translator education: Empowerment from theory to practice (2nd. Ed.). London: Routledge. 
Kiraly, D. C. (2015). Occasioning translator competence: Moving beyond social constructivism toward a postmodern alternative to instructionism. Translation and Interpreting Studies, 10(1), 8-32.

Kumaravadivelu, B. (2006). Understanding language teaching: from method to postmethod. Lawrence Erlbaum Associates, Publishers.

Kuscu, S., \& Unlu, S. (2015). Teaching translation: A suggested lesson plan on translation of advertising through the use of authentic materials. Social and Behavioral Sciences, 199, 407-414.

Lantolf, J. P. (Ed.) (2000). Sociocultural theory and second language learning. Oxford: Oxford University Press.

Larsen-Freeman, D. (2000). Techniques and principles in language teaching ( $2^{\text {nd }}$ Ed.). Oxford: Oxford University Press.

Lesznyák, M. (2007). Conceptualizing translation competence. Across Languages and Cultures, 8(2), 167-194.

Liao, P. (2006). EFL learners' beliefs about and strategy use of translation in English learning. Regional Language Centre Journal, 37(2), 191-215.

Lörscher, W. (1991). Translation performance, translation process, and translation strategies. Tübingen: Gunter Narr.

Lörscher, W. (2005). The translation process: Methods and problems of its investigation. Meta, 50(2), 597-608.

Maftoon, P., \& Amiri, M. (2012). Good language learners' qualifications and social promotion: A case study in the Iranian context. Journal of Studies in Learning and Teaching English, 1(2), 41-64.

McLeod, G. (2003). Learning theory and instructional design. Learning Matters, 2(3), 35-43. Retrieved from http://courses.durhamtech.edu/learningtheory.pdf

McQuillan, J., \& Tse, L. (1995). Child language brokering in linguistic minority communities: Effects on cultural interaction, cognition, and literacy. Language and Education, 9(3), 195-215.

Mitchell, R., \& Myles, F. (1998). Second language learning theories. London: Arnold.

Mogahed, M. M. (2011). To use or not to use translation in language teaching. Translation Journal, 15(4). Retrieved from http://translationjournal.net/journal/58education.htm

Montafej, J., \& Nemati, A. (2014). Investigating translation competence and its subcompetencies through different viewpoints and proposing PACTE group model as the best one. International Journal of Language Learning and Applied Linguistics World (IJLLALW), 5(1), 16-27. 
Mukhari, S. S. (2016). Teachers' experience of information and communication technology use for teaching and learning in urban schools (Doctoral dissertation). University of South Africa.

Munday, J. (2012). Introducing translation studies (3rd Ed.). Oxford: Routledge.

Munday, J. (2015). Engagement and graduation resources as markers of translator/interpreter positioning. Target, 27(3), 406-421.

Munday, J. (4 ${ }^{\text {th }}$ Ed). (2016). Introducing translation studies: Theories and applications. Routledge.

Němec, M. (2011). The pedagogical potential of translation in teaching English. In R. Trušník, K. Nemčoková\& G.J. Bell (Eds.), Theories and practice. Proceedings of the second international conference on English and American studies (pp. 137-146). Zlín: Tomas Bata University.

Nida. E. A. (1993). Language, culture, and translation. Shanghai: Shanghai Foreign Language Education Press.

Nida, E. A. (2004). Toward a science of translating (Vol. 155). Shanghai: Foreign Language Education Press.

Nord, C. (2005). Text analysis in translation: Theory, methodology, and didactic application of a model for translation-oriented text analysis (No. 94). Amsterdam: Rodopi.

O'Malley, J. M., Chamot, A. U., Stewner-Manzanares, G., Kupper, L., \& Russo, R. P. (1985). Learning strategies used by beginning and intermediate ESL students. Language Learning, 35, 21-46.

Oxford, R. (1990). Language learning strategies: What every teacher should know. New York: Newbury House.

Pavlenko, A. (2009). The bilingual mental lexicon: Interdisciplinary approaches. Multilingual Matters.

Petersen, G. (2003). The effects of reading, television viewing, and extracurricular activities on student academic achievement. Unpublished $\mathrm{PhD}$ dissertation, Arkansas State University, Arkansas, U.S.A. Retrieved September 1, 2012, from http://education.astate.edu/dcline/6773/dataproject\%5B1\%5D.htm

Phillips, D. C., \& Soltis, J. (2009). Perspectives on learning (5th ed.). New York.

Struyven, K., Blieck, Y., \& De Roeck, V. (2014). The electronic portfolio as a tool to develop and assess pre-service student teaching competences: Challenges for quality. Studies in Educational Evaluation, 43, 40-54.

Tirkkonen-Condit, S. (2005). The monitor model revisited: Evidence from process research. Meta, 50 (2), 405-414.

Vygotsky, L. (1986). Thought and language. Cambridge: The MIT Press. 
Waibel, A. (2015). Translation training with cross-lingual multi-media support. U.S. Patent Application, 14 (2), 589-658.

Wells, G. (2007). Semiotic mediation, dialogue and the construction of knowledge. Human Development, 50(5), 244-274.

Wilkins, D. (1990). Notional syllabuses ( $2^{\text {nd }}$ Ed.). Oxford: Oxford University Press.

Zhao, K., Hassan, H., \& Auli, M. (2015). Learning translation models from monolingual continuous representations. In J. Mitchell \& M. Lapata (Eds.), Human language technologies: The 2015 annual conference of the North American chapter of the ACL (pp.1527-1536). Denver, Colorado. Publication of Association for Computational Linguistics. 